\title{
Transfer of Lactic Acid Bacterial Strains from the Feed to the Sow, the Environment, and the Piglets
}

\author{
By K. Pedersen, G. W. Christensen, M. Steffensen, P. Schyum and A. K. Johansen \\ Department of Veterinary Microbiology, Royal Veterinary and Agricultural University, Frederiksberg, \\ Denmark.
}

\begin{abstract}
Pedersen, K., G. W. Christensen, M. Steffensen, P. Schyum and A. K. Johansen: Transfer of lactic acid bacteria strains from the feed to the sow, the environment and the piglets. Acta vet. scand. 1992, 33, 297-303. - The spread of lactic acid bacterial strains to the environment and to newborn piglets was investigated after feeding of such strains to sows. Rifampicin resistant bacterial strains were fed to sows, $10^{10}$ c.f.u. per day, during the period from 1 week before expected farrowing until 1 week after farrowing. Fecal samples from the sows and samples of litter were collected for bacteriological examination together with swabs from the pens, the skin of the sows, and from the rectum of the piglets. The test strains were only excreted in relatively low amounts in the feces of the sows, approximately $10^{3}-10^{6}$ c.f.u. per gram. They were not able to displace the normal lactic acid bacterial flora in the sows nor were they transmitted to the intestinal tract of the piglets to any significant extent. After the last administration the test strains disappeared from both feces, skin, and environment, indicating that no permanent colonization had taken place, although considerable differences in duration of persistence were noticed between test strains.
\end{abstract}

lactobacilli; Enterococcus faecium; intestinal tract.

\section{Introduction}

Lactic acid bacteria begin to colonize the gastrointestinal tract of piglets and a number of other animal species shortly after birth (Savage 1977), and during the following days a succession of lactic acid bacterial strains takes place (Tannock et al. 1990a). Experiments based on plasmid profiling indicate that the strains colonizing the intestine of piglets mainly are intestinal strains excreted by the sow (Tannock et al. 1990a). Even in humans evidence for the transfer of Enterobacteriaceae and bifidobacteria from feces of the mother to the infant has been obtained (Tannock et al. 1990b). Lactic acid bacteria are often claimed to play an important part for the well-being of the host (Fuller 1989). Experiments spreading some light on the ecology of lactic acid bacteria with respect to the transfer from mother animal to piglets may be important for the understanding of the acquisition of lactic acid bacteria by the newborn. Furthermore, such experiments may be useful in evaluating the possibilities of administration of potentially beneficial strains to piglets by feeding them to the mother animal. This paper describes an attempt to transfer lactic acid bacterial strains from sows to their newborn piglets by feeding strains to the sows. The excretion of the test strains in the feces of the sows, their contamination of the environment, the bedding, and the skin of the sows, together with the transmission to the digestive tract of the piglets was followed. 


\section{Materials and methods}

\section{Experimental animals}

Four crossbred sows and their piglets were used in the experiments, and housed under standard Danish farming conditions. The sows were kept in separate pens with straw bedding. After farrowing they had access to only approximately one half of their pen, while the piglets had free access to the whole area. The sows received a standard feed mainly based on grained barley with a supplement of protein while the piglets only received maternal milk. Piglets were earmarked and had their tail, deciduous corner incisors, and canine teeth trimmed shortly after birth. Neither sows nor piglets received any medication before or during the experiments.

\section{Bacterial cultures}

One of the sows received a culture of Lactobacillus acidophilus SS28, while a second was given a culture of Enterococcus faecium Cernelle 68 (SF68). The last 2 sows received a mixture of 4 Lactobacillus strains: $L$. salivarius SS129 and SS258, L. gasseri SS131 and L. crispatus SS151. The Lactobacillus strains were all isolated from pigs and were all able to adhere to porcine stratified squamous epithelial cells in vitro as previously described (Pedersen \& Tannock 1989). E. faecium SF68 originated from the probiotic product Cernivet (Bioferment, Lugano, Switzerland) (Lewenstein et al. 1979, Carbone et al. 1980). All strains were rifampicin resistant spontaneous mutants of the parent strains collected on gradient plates of MRS agar (Oxoid) or Mitis-Salivarius agar (Difco) containing rifampicin with a maximum concentration $100 \mu \mathrm{g} / \mathrm{ml}$. The L. acidophilus SS28 strain was propagated in MRS broth (Oxoid) while $E$. faecium SF68 was propagated in brain-heart infusion broth (Difco) at $37^{\circ} \mathrm{C}$.
Overnight cultures were centrifuged for 20 $\mathrm{min}$ at $6000 \mathrm{rpm}$. Pellets were resuspended in fresh broth, added $20 \%$ sterile glycerol and kept at $-80^{\circ} \mathrm{C}$ in ampoules containing $10^{10}$ c.f.u., 1 ampoule for each day. The mixture of the 4 Lactobacillus strains was freeze dried in a carrier medium of glucose and electrolytes and packed in air and light tight metal envelopes each containing $10^{10}$ viable cells (Chr. Hansen's Bio Systems, Hørsholm, Denmark). The stability of the rifampicin resistance was examined by repeated subculture in MRS broth or brain-heart infusion broth without rifampicin. After incubation at $37^{\circ} \mathrm{C}$ for $24 \mathrm{~h}$ subcultures were made on MRS or Mitis-Salivarius agar plates with and without rifampicin.

\section{Administration of cultures and collection of samples}

From 1 week before expected farrowing until 1 week after farrowing the sows received a daily dose of $10^{10}$ c.f.u. of 1 of the test cultures by adding cultures to the feed. Usually, all feed was eaten within $30 \mathrm{~min}$ after feeding. The administration periods ranged between 15 and 18 days. Until farrowing fecal samples and samples of the bedding were collected every 2 or 3 days. Feces were collected from rectum. Furthermore, swabs were taken from the environment. With a metal template a $10 \mathrm{~cm}^{2}$ surface area was swabbed with a sterile cotton swab at 5 different sites in the pens, from both floor and equipment. Similarly, $10 \mathrm{~cm}^{2}$ of skin were swabbed at 5 different sites on the ventral part of the sow, including the udder. After farrowing the sampling also included rectal swabs from 5 piglets from each litter, randomly selected and marked with numbers from 1 to 5. During the first 2 weeks samples were collected every 2 or 3 days. Thereafter the intervals were prolonged, but sampling 
continued until the test strains were no longer detectable. All swabs were immediately transferred to tubes with Stuart Transport Medium (Difco). All samples were kept at $0-5^{\circ} \mathrm{C}$ until laboratory treatment (less than 2 h).

\section{Culture from samples}

Feces and litter samples were suspended in sterile saline as 10 -fold dilutions (wt/vol) from which further 10 -fold dilutions ( $\mathrm{vol} / \mathrm{vol}$ ) were made. The 5 swabs from the environment were pooled in saline and mixed on a whirlmixer, and likewise the 5 swabs from the skin. Ten-fold dilutions from saline (vol/vol) were made. Rectal swabs from the piglets were treated separately. In experiments with Lactobacillus strains inoculation from relevant dilutions took place on Rogosa SL agar (Difco) and Rogosa SL agar added rifampicin $50 \mu \mathrm{g} / \mathrm{ml}$ for the enumeration of total lactobacilli and test strains, respectively. Plates were incubated anaerobically in an atmosfere of $\mathrm{N}_{2}, \mathrm{H}_{2}$, and $\mathrm{CO}_{2}$ (GasPak jars, BBL Microbiology Systems, Cockeysville, Md.) for 2 days at $37^{\circ} \mathrm{C}$. In the experiment with $E$. faecium SF68 relevant dilutions were plated on Mitis-Salivarius agar (Difco) with and without rifampicin, $100 \mu \mathrm{g} / \mathrm{ml}$, for the enumeration of total streptococci/enterococci and E. faecium SF68, respectively. Mitis Salivarius agar was supplied with nalidixic acid, $15 \mu \mathrm{g} / \mathrm{ml}$, instead of Chapman tellurite (Barrow et al. 1977). Plates were incubated aerobically for 2 days at $37^{\circ} \mathrm{C}$. Results were expressed as c.f.u. per gram (feces and litter), per 5 swabs $\left(50 \mathrm{~cm}^{2}\right.$ from skin and environment), or per rectal swab.

\section{Results}

In all experiments using Lactobacillus cultures the total fecal excretion of lactobacilli by the sows was very stable, approximately $10^{8}-10^{9}$ viable counts per gram. Counts from 1 of the sows given the mixture of 4 Lactobacillus strains are shown in Fig. 1. In the

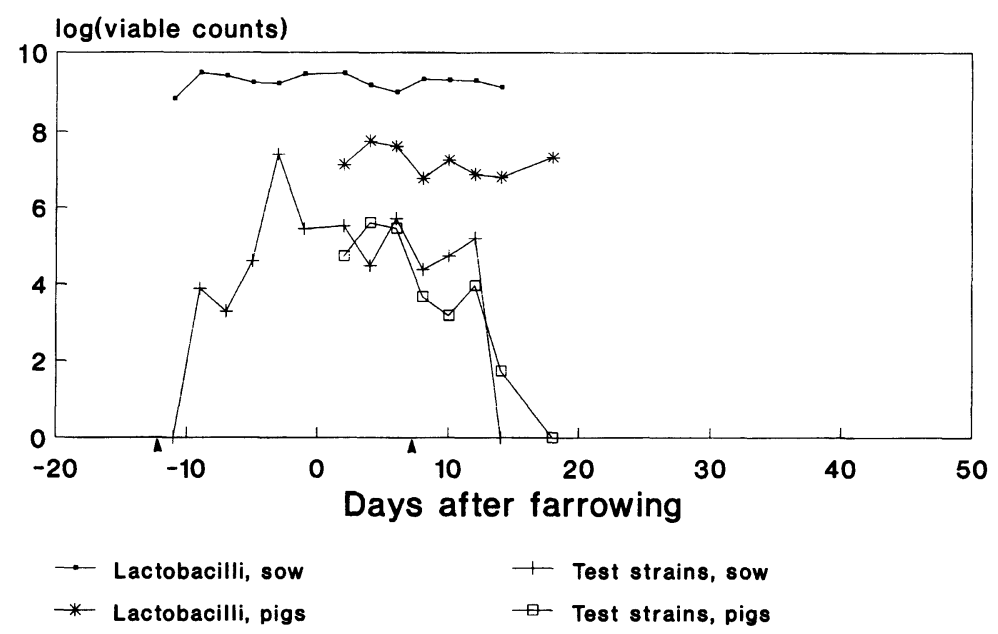

Figure 1. Fecal counts of total lactobacilli and Lactobacillus test strains in the sow and the piglets (average of 5 piglets). Counts for the sow are expressed as viable counts per gram feces and for the pigs as viable counts per rectal swab.Test strains were a mixture of 4 Lactobacillus strains. First and last day of administration of test strains to the sow is indicated with arrows. 


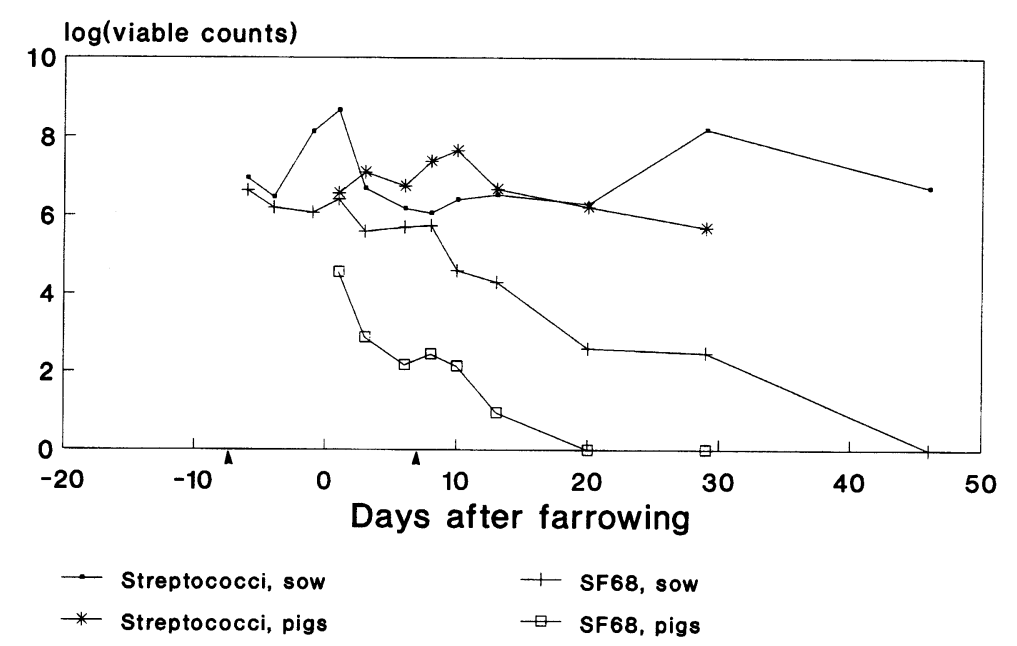

Figure 2. Fecal counts of total streptococci/enterococci and Enterococcus faecium SF68 in the sow and the piglets (average of 5 piglets). Counts for the sow are expressed as viable counts per gram feces and for the pigs as viable counts per rectal swab. First and last day of administration of SF68 to the sow is indicated with arrows.

experiment with $E$. faecium SF68 the total counts of streptococci/enterococci were more fluctuating, but generally ranged in the interval $10^{7}-10^{8}$ c.f.u. per gram (Fig. 2). The counts of the test strains in fecal samples increased during the first few days and reached a maximum 5 - 8 days after the first administration. Thereafter the counts dropped significantly.

None of the Lactobacillus test strains reached a higher proportion than about $2.5 \%$ of the total Lactobacillus counts in feces of the sows (data not shown). In contrast the $E$. faecium SF68 strain was able to reach a much higher proportion of the total Streptococcus/Enterococcus flora, up to $50 \%$. Already 3 days after the final administration, however, the fraction had fallen below $1 \%$. In litter samples and swabs from the environment the total counts of Lactobacilli and Streptococci/Enterococci fluctuated more than in fecal samples but ranged around $10^{7}$ viable cells per gram and per $50 \mathrm{~cm}^{2}$, respectively (data not shown). Counts in swabs from the skin fluctuated considerably.

After the last administration, the Lactobacillus strains maintained populations about $10^{4}$ - $10^{5}$ c.f.u. per gram of feces for a short period. The Lactobacillus mixture strains maintained these counts for 5 - 7 days (Fig. 1) but the SS28 strain only for 3 days (data not shown). Thereafter the excretion of these strains abruptly dropped. This drop was reflected in the counts from skin and in litter and environment. Four days after the last administration the SS28 strain could no longer be detected. The E. faecium strain disappeared more gradually (Fig. 2) and could be detected longer than any of the lactobacilli. Twentytwo days after the last administration it could still be detected in both feces, litter, skin, and environment but at 39 days it had disappeared.

Counts of test strains and total Lactobacillus 
in piglets from one litter receiving the four Lactobacillus strains are shown in Fig. 1, while counts of E. faecium SF68 and total Enterococcus/Streptococcus are shown in Fig. 2. The excretion of the test strains by the piglets reached a maximum within a few days and thereafter dropped, although the strains were still fed to the sows. The highest counts of the test strains were observed for almost all piglets at day $1-3$, but even then they only constituted a very small fraction of the total counts of lactobacilli and streptococci/enterococci, respectively, usually below $1 \%$. However, there was a considerable variation between the piglets in each litter. In 1 of the 2 litters from sows receiving the mixture of the 4 Lactobacillus strains the test strains constituted $22.5 \%$ of the lactobacilli in 1 piglet 6 days after birth - a sudden and remarkable rise from $0.08 \%$ at day 4 (Table 1 ).

\section{Discussion}

None of the test cultures were transmitted to the piglets to any significant extent, and none of them were able to colonize permanently inside or outside the animals, although considerable differences in persistence were noticed between strains. They disappeared

Table 1. Counts of test strains in rectal swabs of piglets from 1 sow receiving a mixture of 4 Lactobacillus strains expressed as \% of the total Lactobacillus counts.

\begin{tabular}{llllll}
\hline $\begin{array}{l}\text { Days after } \\
\text { birth }\end{array}$ & Piglet 1 & Piglet 2 & Piglet 3 & Piglet 4 & Piglet 5 \\
\hline 2 & 1,78 & 0,34 & 0,01 & 0,02 & 0,08 \\
4 & 0,08 & 0,43 & 0 & 2,3 & 0,001 \\
6 & 22,5 & 0,003 & 0,004 & 3,1 & 0,02 \\
8 & 3,4 & 0,001 & 0 & 0,06 & 0 \\
10 & 0,49 & 0 & 0 & 0,004 & 0 \\
12 & 0,21 & 0,006 & 0 & 0,005 & 0 \\
14 & 0,013 & 0,006 & 0 & 0 & 0 \\
17 & 0 & 0 & 0 & 0 & 0 \\
\hline
\end{tabular}

from both animals and environment within 4 - 39 days after the last administration. These results are in accordance with those from other experiments (Jonsson 1985, Jonsson et al. 1985, Pedersen \& Tannock 1987, Pedersen \& Tannock 1989). Jonsson (1985) showed that lactic acid bacterial strains fed to newborn piglets could be detected in the feces after 7 days, but had disappeared at 19 days. No effect on performance was observed in her study. Results presented in the literature suggest that a succession of lactic acid bacterial strains takes place in neonatal piglets (Tannock et al. 1990a). This may indicate that strains are usually only able to colonize for a certain period of time and thereafter will be supplanted by other strains. However, the capacity of 1 particular strain to colonize more permanently in humans has been suggested (Goldin \& Gorbach 1987). The mechanisms behind the succession of lactic acid bacteria are poorly understood. The Lactobacillus strains in the present study all originated from the digestive tract of piglets and were able to adhere to porcine squamous epithelial cells in vitro. The strains are therefore considered indigenous porcine Lactobacillus strains, although they have been shown to be unable to colonize permanently in a previous inoculation study in piglets where they only persisted for a certain period and with considerable differences between strains (Pedersen \& Tannock 1989). The E. faecium SF68 strain was tested because it is probably the most popular probiotic strain in the world, both for animals and humans.

In most samples collected from the piglets the test strains constituted less than $1 \%$ of the total Lactobacillus or Streptococcus/Enterococcus flora. In 1 piglet, however, from 1 of the litters receiving the Lactobacillus mixture, the figure suddenly rose from $0.08 \%$ at day 4 to $22.5 \%$ at day 6 followed by 
a decline to $3.4 \%$ and $0.49 \%$ at day 8 and 10 , respectively. In this piglet the test strains appeared to establish and multiply for a few days.

The lack of ability to survive in the environment for all test strains, together with the close parallellity between the excretion of the strains in the feces and the counts retrieved in the environment, indicates that the main source of these strains was the mother animal and that essentially no multiplication took place outside the digestive tract. The results therefore suggest that the mother animal was the primary source of the piglets' flora of lactic acid bacteria. This is in accordance with recently published results (Tannock et al. 1990a).

The maximum fecal excretion of the test strains from the sows occurred after $5-8$ days, i.e. more than 1 week before the last administration. The reason for this is unknown. It was observed in all 4 sows and also in the piglets from which the maximal excretion was reached 1 - 3 days after birth.

For a period E. faecium SF68 constituted more than half the total Enterococcus/Streptococcus flora in feces from the sow and it disappeared more slowly than did the Lactobacillus test strains. This may be explained by a better ability to survive in the environment or capacity to persist in the intestine.

The highly fluctuating counts for all test cultures obtained in swabs from the skin may be considered to merely reflect the degree of fecal contamination rather than any colonization of the skin by these microorganisms.

It was not possible from the present data to detect any differences in colonization patterns between freeze dried cultures and frozen broth cultures. Further experiments should be carried out to examine this question.

The rifampicin resistance was found to be a stable trait as was described by other authors (Compeau et al. 1988). Naturally occurring resistance to rifampicin among Danish porcine lactobacilli and enterococci is negligible (Pedersen unpublished observation).

It was concluded that the intestinal Lactobacillus flora of the sows was too stable to be affected to any significant degree by the chosen doses of any of the test cultures, whereas the Streptococcus/Enterococcus flora was markedly influenced by the E. faecium strain.

\section{References}

Barrow PA, Fuller R, Newport MJ: Changes in the microflora and physiology of the anterior intestinal tract of pigs weaned at 2 days, with special reference to the pathogenesis of diarrhea. Infect. Immun. 1977, 18, 586-595.

Carbone M, Bonina L, Fera MT: Microbiological properties of Streptococcus faecium SF 68 strain and its relationships with other microorganisms. Boll. Ist. sieroter. milan. 1980, 59, 591-598.

Compeau G, Al-Achi BJ, Platsouka E, Levy SB: Survival of rifampicin-resistant mutants of Pseudomonas fluorescens and Pseudomonas putida in soil systems. Appl. environ. Microbiol. 1988, 54, 2432-2438.

Fuller R: A review. Probiotics in man and animals. J. appl. Bact. 1989, 66, 365-378.

Goldin BR, Gorbach SL: Lactobacillus GG: A new strain with properties favourable for survival, adhesion and antimicrobial activity in the gastrointestinal tract. FEMS Microbiol. Rev. 1987, 46, P72, F1.

Jonsson E: Persistence in the gut of suckling piglets of a Lactobacillus strain and its influence on performance and health. In: Just A, Jørgensen $H$, Fernandez $J A$ (eds): Proceedings of the 3rd International Seminar on Digestive Physiology in the Pig, Copenhagen 16th - 18th May 1985. 580. Beretning fra Statens Husdyrbrugsfors $\varnothing$, Landhusholdningsselskabets Forlag, Frederiksberg, 1985, 288-291.

Jonsson E, Björck L, Claesson CO: Survival of orally administered Lactobacillus strains in the gut of cannulated pigs. Livest. Prod. Sci. 1985, 12, 279-285

Lewenstein A, Frigerio G, Moroni M: Biological properties of SF 68, a new approach for the 
treatment of diarrheal diseases. Curr. ther. Res. 1979, 26, 967-981.

Pedersen K, Tannock GW: Colonization and persistence of two Lactobacillus strains in the digestive tract of piglets. FEMS Microbiol. Rev. 1987, 46, P47, F5.

Pedersen K, Tannock GW: Colonization of the porcine gastrointestinal tract by lactobacilli. Appl. environ. Microbiol. 1989, 55, 279-283.

Savage DC: Microbial ecology of the gastrointestinal tract. Ann. Rev. Microbiol. 1977, 31, 107 133.

Tannock GW, Fuller R, Pedersen K: Lactobacillus succession in the piglet digestive tract demonstrated by plasmid profiling. Appl. environ. Microbiol. 1990a, 56, 1310-1316.

Tannock GW, Fuller R, Smith SL, Hall MA: Plasmid profiling of the family Enterobacteriaceae, lactobacilli, and bifidobacteria to study the transmission of bacteria from mother to infant. J. clin. Microbiol. 1990b, 28, 1225-1228.

\author{
Sammendrag \\ Spredning af malkesyrebakterier fra foderet til soen, \\ miljøet og grisene.
}

Spredningen af stammer af mælkesyrebakterier til miljøet og pattegrisene blev unders $\varnothing \mathrm{gt}$ efter tildeling af stammerne til søerne via foderet. Rifampicinresistente teststammer blev i mængder af $10^{10}$ c.f.u. pr. dag tildelt søerne fra en uge før forventet faring til en uge efter faring. Fæcespr $\varnothing v e r$ fra søerne og prøver af strøelsen blev udtaget til bakteriologisk unders $\varnothing$ gelse sammen med svaberprøver fra stierne, fra søernes hud og fra rectum af grisene. Teststammerne blev kun udskilt i fæces fra søerne i relativt lave antal, omkring $10^{3}-10^{6}$ c.f.u. pr. g. De var således ikke i stand til at fortrænge den naturlige flora af mælkesyrebakterier i tarmen, ligesom de heller ikke i nævneværdig grad blev overført til grisenes tarmkanal. Efter sidste tildeling af teststammerne forsvandt disse fra såvel fæces som fra huden og miljøet. Der forekom således ingen permanent kolonisering, men der var dog betydelige forskelle $\mathrm{i}$ persistens mellem de enkelte testkulturer.

(Received March 23, 1992; accepted July 2, 1992).

Reprints may be requested from: K. Pedersen, Department of Veterinary Microbiology, Royal Veterinary and Agricultural University, 13 Bülowsvej, DK-1870 Frederiksberg C, Denmark. 